\title{
Tenure Security and Urban Social Protection Links: India
}

\author{
Darshini Mahadevia*
}

\begin{abstract}
Guaranteeing tenure security to the households living in informal settlements (slums) has not seen any progress in urban India. This is because the policymakers have failed to see land tenure status as a continuum from insecure tenure to a legal status. In general, the poor in the cities move from informal to quasi-legal (de facto) tenure through various processes, and then to legal tenure (de jure) in cases of a public policy intervention that confers property title on them. In the absence of such a policy, the urban poor and low-income migrants can seek to consolidate their urban citizenship through political citizenship in an electoral democracy, through welfare interventions by the state and above all, through their own subversions of urban legalities. This article first illustrates the existence of a continuum of tenure status in informal settlements in Ahmedabad City. It explains the factors that give a slum settlement a particular level of tenure status; and then through quantitative data, links the level of tenure security to social protection outcomes. The article shows that through small public actions, it is possible to improve access of the urban poor to social protection measures and that it is not necessary to leapfrog to extending property rights to the dwellers of these informal settlements. It is essential to realise that if land titles are given in a society where other rights are not present, the poor will not be able to retain them.
\end{abstract}

\section{Introduction: different degrees of residential security}

Security of tenure is considered next only to food and water in importance in urban living (Oberlander 1985), a declaration first made at the Habitat Conference held in Vancouver in 1976 and reiterated since then in all the Habitat Conferences and World Urban Forums. Access to tenured land is considered an extremely important instrument of urban poverty alleviation, as it addresses the issue of basic needs. Following tenure security are the extension of water supply and sanitation in the informal settlements, leading to improvement in local quality of life and, in turn, health. In the social protection literature, access to land is considered important for transformative social protection in the absence of universalisation of social protection measures, since this also reduces deprivation. In addition, in urban areas of developing countries, land tenure gives legal identity to the vast majority of urban residents, and in particular the new low-income migrants, thereby conferring urban citizenship to them.
Access to tenured urban land leads to capital formation among the poorest of the urban population, something economists view as the penetration of capitalism at the bottom of the pyramid. Secure shelter is both status-enhancing and of intrinsic value. The State of the World's Population, 2007, a report by the United Nations Population Fund (UNFPA), argues that the current urban transition will not be humane if the land needs of the poor are not met (UNFPA 2007:3).

Having established the importance of land tenure, what is meant by it? Payne (2000) defines land tenure as the mode in which land is held or owned and the set of relationships it establishes among people concerning the land or its product. It is different from property rights which are defined as a recognised interest in land or property vested in an individual or group (Durand-Lasserve and Royston 2002). In other words, land tenure status indicates people's level of security in the use of land, whereas property rights indicate its defensible legal ownership. ${ }^{1}$ 
Security of tenure is determined by, on the one hand, the constitutional rights guaranteed by a state to its citizens and, on the other, by the legal and administrative framework within that state. This framework may include both customary and statutory systems. In addition, security of tenure can be affected by the social norms and cultural values of a society. In sum, tenure security is a complex entity which provides protection to a household or individual against their involuntary removal from their house or land without due process of the law.

Payne (2000) has argued that there are different levels of tenure security within the informal housing markets, from temporary squatting to a quasi-legal right to the land. In general, the poor in the cities can move from informal to quasilegal (de facto) tenure through various processes, and then to legal tenure (de jure) in the case of a public policy intervention that confers property title on them. In the absence of such a policy, the urban poor and low-income migrants can seek to consolidate their urban citizenship through political citizenship in an electoral democracy, through welfare interventions by the state and above all, through their own subversions of urban legalities. There are thus three categories of land tenure status: insecure, de facto and de jure.

This process of housing mobility among lowincome settlements has been explained through demand-side models as well as supply-side policies. The demand-side models, coming from economists, have linked housing mobility with income mobility and life cycle mobility. These demand-side models are 'progressive housing development' (from Turner 1967, 1968; and Keare and Parris 1982) and the 'incremental housing investment model' conceived by Hamer (1985). This understanding of housing mobility has influenced the design of slum upgrading programmes by the World Bank since the early 1970s. The argument here is that an increase in income would lead to housing investments. The supply side analysts and hence their proponents have argued that access to tenured lands can also be ensured through political action such as the planned invasion of public lands or the large scale supplying of small lots in periurban areas, as President Salvador Allende attempted in Chile in the 1970s (Edwards 1983). Hansen and Williams (1987) have brought together the demand-side and supply-side explanations with policy recommendations into a 'progressive housing model', which has four stages: (1) stage zero - pre-ownership (rental housing); (2) stage one - initial settlement; (3) stage two - selfmotivated upgrading and (4) stage three external-shock-motivated upgrading. The first three stages relate to the duration of stay in the city and the stage of people's life cycle, whereas the last stage relates to public policy. External shocks in the form of public policies to do with tenure guarantee can lead to upgrading that consolidates low-income households in the urban system. In short, the debate has been between those arguing for leaving housing mobility of the low-income households up to the market (including policy support for those markets), and those arguing for proactive public policy to increase low-income housing supply, either through building public housing or tenure guarantee interventions.

Also, a longstanding debate regarding land tenure for the urban poor has been whether to guarantee secure tenure through a rights-based approach or to confer property titles on the poor. The market theorists have argued for the latter, a vocal proponent of this position being Hernando de Soto. The former would lead to access, use, development and transfer of land without legal ownership. However, there are arguments against de Soto's position. 'Empirical evidence points to a continuum of security in illegal settlements that depends less on the exact legal status and more on occupants' perceptions of the probability of eviction and demolition (enforcement); as well as the availability of services and passage of time' (Gilbert 2001). Payne (1997) argues that land rights are part of other rights in a society and cannot come into force in the absence of other rights. Thus, if land titles are given in a society where other rights are not present, the poor will not be able to retain them. Further, when informal land rights are legalised by conferring property titles, such lands become open to outright purchase, resulting in marketbased displacements of the poor from prime urban locations. Thus, it is safer to move gradually toward establishing shelter rights while avoiding pushing informal land markets into a private property regime, particularly in the light of currently increasing urban inequality in developing countries. In other words, we argue here for instruments to increase de facto, or perceived, security of tenure. 
This study, through primary research in Ahmedabad City, ${ }^{2}$ attempted to link a proactive policy of extending de facto tenure security to slum dwellers to both improvement in living conditions and extension of social protection. The next section briefly introduces Ahmedabad, its policy regime and levels of tenure security observed in Ahmedabad City. Third, a section on methodology explains the variables chosen to measure social protection. Next, we present the statistical findings and the final section concludes with observations regarding urban public policies in India.

\section{Ahmedabad's slum development policies}

Ahmedabad is the largest metropolis of Gujarat state, India's second most industrialised city (Hirway and Mahadevia 2005). Today, local conflict has segmented the city into Hindu and Muslim $\operatorname{areas}^{3}$ (Mahadevia 2007). The city is home to several large non-governmental organisations (NGOs), some of which have engaged with slum communities since 1997, implementing an innovative development programme called the Slum Networking Programme (SNP). ${ }^{4}$

Ahmedabad experienced severe crises from the late 1980 s to the late 1990 s during which its main economic base, cotton textile mills, closed down and a large section of the labour force was displaced from the formal to the informal sector (Mahadevia 2002). The retrenched labour shifted to the power-loom industries, halving workers' wages, and to self-employment -37 per cent of men and 65 per cent of women were selfemployed in 1999-2000 (Mahadevia 2008a) without any social security.

An estimated 41 per cent of the city's population lived in slums in 1990 (ASAG 1992). A more recent estimate gives 26 per cent as slumdwellers, ${ }^{5}$ and the 2005 population census gives an estimate of 13 per cent (Office of the Registrar General and Census Commissioner, India 2005: 22). A primary survey of the slums by the Mahila Housing Trust (MHT) on behalf of the Ahmedabad Municipal Corporation (AMC) in early 2000 , states that there are around 710 slums in the city, housing around 0.9 million people. ${ }^{6}$

In legal terms, slums can be either 'notified' or 'non-notified'. The former has a quasi-legal status and would qualify for basic services extension by the Urban Local Body (ULB); in the case of Ahmedabad, the AMC. The non-notified slums may not qualify for the ULBs' development programmes, as these might grant residents $d e$ facto tenure. The categories of 'notified' and 'nonnotified', 'regularised' and 'non-regularised', are used to determine inclusion or exclusion of slums in subsidised urban development programmes, the notified or regularised slums being eligible. Thus, these binaries determine the extension of rights to the urban poor. Urbanisation is a continuous process, so that at any time there are large numbers of people without legal urban residency, the poor among them living in squatter and slum settlements.

The state of Gujarat does not have any tenure regularisation programme, but the AMC has various slum development programmes. These are: (1) the 90:10 scheme where the AMC contributes 90 per cent of the cost of household water connection and toilet construction; (2) a No Objection Certificate (NOG) given by the AMC to the slums allowing individual water supply and sewerage connections; and (3) the SNP.

Besides these, the AMC is also implementing a public housing programme funded by the national government under the Jawaharlal Nehru National Urban Renewal Programme (JNNURM). This national programme scheme will construct 50,000 housing units for the urban poor $^{7}$ and assign them to the displaced slum dwellers via various city-level development programmes. The beneficiaries of this programme are those with a proof of identity cards, issued to slum dwellers in 1976, some 33 years ago. Duration of stay in the city therefore becomes a criterion for extending tenure security to slum dwellers. Those who have lost these ID cards in one of the disasters during this period, such as floods, conflict and fires, would lose their eligibility. This study does not cover residents of such public housing schemes.

The SNP has two main components: first, improvement in physical environment, ${ }^{8}$ which enhances promotional social protection, and second, a community development and social infrastructure component, ${ }^{9}$ which could assist in transformative social protection. The entire programme is community-driven, with local government and the AMC in extending basic services to the slum settlements and providing a 
ten year 'no eviction guarantee'. The first component extends de facto tenure security resulting in an improvement in living conditions and thereby reducing deprivation; in other words, extending promotional social protection. The second component is based on community mobilisation, which is expected to empower the community, resulting in transformative social protection. So far, some 60 slums and 13,000 households have been covered under the SNP. ${ }^{10}$ The SNP therefore qualifies as a programme extending strong de facto tenure security.

The first two slum development programmes of the AMC extend some level of de facto tenure security, but not to the same extent as the SNP. Thus, these two programmes extend weak de facto tenure security. Extension of basic services to the slums has led to property tax bills being sent to households there, even to those without legal land titles, by the AMC in an effort to widen its property tax base and increase its revenue. Interestingly, however, this has inadvertently extended quasi-security or de facto tenure security to the slum households. Thus we consider receipt of property tax bills as an indicator of weak de facto tenure security. During our focus group discussions with the slum dwellers, they expressed this as their one of their central demands to the AMC. Other measures come under the category of citizens' entitlements such as getting a voter ID card and a ration card. There are two types of ration cards, the Below Poverty Line (BPL) card extended to those falling below a poverty line cut-off ${ }^{11}$ and the Above Poverty Line (APL) card. The ration card has an address and hence gives some citizenship rights to the holder.

The state, through its inaction, also grants some level of tenure security. For example, if a slum exists for a long time without its residents being evicted it will grow, and its dwellers will consolidate their lives in the city. The residents use their own mechanisms to get ration cards and voter ID cards. Many such slum settlements in Ahmedabad have developed on private land due to legislation such as the 1976 Urban Land Ceiling and Regulation Act, which was promulgated by the national government and adopted by the state government, and stated that lands in excess of a certain size would be confiscated for the development of low-income housing. This was a measure designed to prevent monopolisation of land, in reaction to which the private landowners subdivided their holdings and sold them to low-income households. The private land declared reserved for various public purposes under the city's development plan were also subdivided and sold to low-income households. In the absence of any public housing programme or policy for low-income households, these subdivided plots were sold quickly. These developed into slums, so that today, more than half of the slum households in Ahmedabad are on private land, with any of the three tenure security categories described above.

Lastly, there are slums in the city which lack any of the above forms of security and may soon be displaced. Slums of this type are those in the 'right of the way' of existing or proposed roads or on lands reserved for 'public purposes'. Slums on public lands also come under this category since the lands may be designated for use under the city's development plan. Those with a 1976 ID card can get rehabilitation under the JNNURM public housing, and those without it will have to start all over again if displaced. These slums are therefore categorised as insecure.

\section{Methodology}

Summarising the discussion on the slum development policies in Ahmedabad, we can see that tenure security is largely defined at slum settlement level rather than at household level. We can also see that there are four different levels of tenure security to be found in the slums in Ahmedabad City, defined by various actions and inactions of the national, local (AMC) and the state government. These are:

1 Legal housing and hence de jure tenure, through new public housing programmes such as the JNNURM

2 Short-term but strong de facto tenure through the SNP

3 Weak de facto tenure security or enhanced perceived security of tenure through: extension of basic services as welfare measures by the ULB, extension of entitlements such as the Voter ID Card and a BPL/APL Card, and administrative instruments such as Property tax bill

4 Insecure tenure, where there is none of the above, and where the slum is on the land reserved for public purposes, is small in size or new. 
Table 1 Levels of tenure security

\begin{tabular}{llll}
\hline Tenure & High de facto & Weak de facto & Insecure \\
\hline External agency intervention & Yes & & \\
Land document & Yes & Yes & \\
Land reservation in master plan & No & No & Yes \\
Administrative instruments & Yes & Yes & Yes \\
Entitlement extension & Yes & Yes & Yes \\
Extension of basic services & Yes & Yes & Yes \\
Duration of stay & Yes & Yes &
\end{tabular}

Strong or weak de facto security can also be attained through State inaction, where the slum dwellers are left to their own devices, and over time, muster their own personal resources, financial and social, to attain some level of shelter security. The key factors in this process are inaction by the state, and duration of residence. The longer the slum remains in the same location, the higher the residents' perceived level of security. The literature suggests that the size of the settlement also matters, particularly in electoral politics where numbers are important. Thus, both duration of stay and size of settlement matter for tenure security in case there is no state policy or action.

Using this discussion, we have classified levels of tenure security into three categories using the variables presented in Table 1. Instead of a statistical method of indexing or scoring, we have used our judgement, emerging from our discussions with the slum communities to assign a particular tenure security category to a slum settlement.

The authors have also carried out bivariate logit regression analysis to observe the relationship between each of the factors (as listed in Table 1) constructing level of tenure security (treated as independent variables) and dependent variables of outcomes in social protection. Presented below (see Table 3) are the logit regression results of duration of stay with social protection outcomes. The dependent variable is 1 if duration of stay is more than 20 years and 0 if less than 20 years.

Primary survey data was collected from six slum settlements in the Vasna ward of the city. In all, 553 samples were drawn from a total of 3,514 households. The sample covered 5,327 individuals. To identify settlements, first a list of all the settlements in each ward was obtained along with the data on all the basic information of the settlement, except land tenure status. Using the criteria of location, slum size, land ownership, and institutions present in the settlement, slums were shortlisted for detailed scrutiny. Our research team visited all the shortlisted slums to get further details of land tenure, as defined by the criteria mentioned above, from which six settlements were identified in each ward. Thereafter, in each selected slum, a community mapping was done for the purpose of stratified sampling.

In our sample, two slums had been developed under the SNP programme; one named Pravinnagar-Guptanagar had an intervention by Saath, a development NGO and another, Jadibanagar, assisted by the MHT. Further, the MHT has a presence in Sorainagar, the third slum in the sample and Saath has begun forming women's savings groups in Mangal Talaav Chhapra (slums on lake named Mangal). The slums have thus seen some development interventions by external agencies. Lastly, the AMC has extended basic infrastructure services to five of the six slums selected, including Mangal Talaav Chhapra, which has been classified as having insecurity of tenure. Yogeshwarnagar and Shri Omnagar have not had any NGO interventions, but the latter has basic services. Part of Shri Omnagar is marked for eviction, as is Mangal Talaav Chhapra. If the slums were to be divided into three tenure categories, Pravinnagar-Guptanagar and Jadibanagar would classify as slums with high de facto tenure security; Sorainagar and Shri Omnagar as having weak de facto tenure security and Mangal Talaav Chhapra and Yogeshwarnagar as having insecure tenure. 
Table 2 Social protection indicators by tenure status, Ahmedabad

\begin{tabular}{|c|c|c|c|c|}
\hline \multirow[t]{2}{*}{ Indicators } & \multicolumn{3}{|c|}{ Tenure (\%) } & \multirow[t]{2}{*}{ Average (\%) } \\
\hline & $\begin{array}{l}\text { Strong } \\
\text { de facto }\end{array}$ & $\begin{array}{l}\text { Weak } \\
\text { de facto }\end{array}$ & Insecure & \\
\hline Housing quality - Katcha houses & 32 & 39 & 54 & 42 \\
\hline Housing quality - Pucca houses & 42 & 39 & 24 & 35 \\
\hline Households with individual water supply from the AMC & 90 & 29 & 19 & 45 \\
\hline Households depending on public taps for water supply & 4 & 18 & 52 & 26 \\
\hline Households not having access to a toilet & 0 & 5 & 2 & 2 \\
\hline Households having individual toilet for the household & 94 & 86 & 69 & 82 \\
\hline Households using community toilets & 1 & 1 & 18 & 7 \\
\hline Males literate & 81 & 84 & 72 & 78 \\
\hline Females literate & 58 & 59 & 55 & 57 \\
\hline Male children going to school & 72 & 89 & 81 & 81 \\
\hline Female children going to school & 69 & 85 & 77 & 79 \\
\hline Average per capita income per month (Rs) & 908 (Rs) & 895 (Rs) & 744 (Rs) & 842 (Rs) \\
\hline Work participation rate: male & 54 & 50 & 52 & 52 \\
\hline Work participation rate: female & 27 & 19 & 33 & 27 \\
\hline Male employed as casual labour & 51 & 58 & 82 & 64 \\
\hline Male in private services & 34 & 18 & 16 & 23 \\
\hline Male employed in social, financial and government services & 2 & 1 & 0 & 1 \\
\hline Female employed as casual labour & 34 & 41 & 41 & 39 \\
\hline Female in private services & 53 & 34 & 48 & 47 \\
\hline Female employed in government services & 1 & 1 & 0 & 1 \\
\hline Households saving & 33 & 17 & 23 & 24 \\
\hline Average savings per month (Rs) & 231 (Rs) & 196 (Rs) & 122 (Rs) & 198 (Rs) \\
\hline Households having ration card & 85 & 88 & 73 & 82 \\
\hline Households having voter ID cards & 95 & 95 & 88 & 92 \\
\hline
\end{tabular}

Katcha: houses built with temporary materials in roof and walls. Pucca: houses built with permanent materials in roof and walls.

\section{Tenure security and social protection}

The working hypothesis that guided our research is that security of tenure facilitates access to social protection and to improved quality of life. In this section, we present our preliminary findings in relation to this hypothesis. As mentioned, this research is based on data collected from Vasna ward, located in the southwestern part of Ahmedabad City. This was formerly a peripheral ward lacking basic municipal services such as water supply networks, sewerage and drainage networks, and waste management system. In a survey carried out in this ward in 2005, it was found that the availability of basic services was poor, except in the slum where the SNP was implemented (Mahadevia and Brar 2008). The situation has improved significantly since then and trunk infrastructure has been laid.

The first direct impact of improvement in tenure status is investments by the households in improving their shelter conditions. This 
improvement is incremental; walls constructed of temporary materials are made permanent; temporary roofs are made permanent and so on. The shelter upgrading priorities in low-income settlements are: (1) repairing a leaking roof; (2) converting mud walls into brick walls with cement mortar; (3) making tiling floors; (4) connecting to water supply; (5) building individual toilets; (6) connecting to electricity supply; (7) extending the house and (8) buying a new house or hut. The benefits of each of these improvements are: (a) a water connection saves time; (b) roof repairing saves or protects the quality of goods, especially for home-based producers; (c) electricity facilitates longer working hours, which in turn increases productivity and thus income; (d) clean drinking water reduces illness and saves expense on healthcare and by that makes income available for other purposes such as education, income-generation, buying durable assets, etc.; (e) tiled floors also improve productivity for home-based workers; (f) brick walls with cement mortar save recurring expenses of repairing walls after intense rains or flooding, and $(\mathrm{g})$ house extension is useful for expanding home-based production activities, renting out for earning additional income and keeping the extended family together.

The different variables indicating improvement in shelter conditions with increase in tenure security can be seen from the data in Table 2. To repeat, the tenure security construct includes factors such as duration of stay, land transaction document held by the household if any, external intervention such as by an NGO, state policy of extending basic services, administrative actions and entitlement extension. Some 54 per cent of households in the insecure tenure category lived in katcha, or temporary, houses where this proportion in strong de facto tenure slums is 32 per cent. Overall, 42 per cent of households in the slums surveyed lived in katcha housing, indicating a great need to improve housing conditions. Conversely, 42 per cent of households with strong de facto tenure and just 24 per cent of households with insecure tenure had a pucca house. Basic service availability also improves with an improvement in tenure status: 90 per cent of households with strong de facto tenure had access to individual water supply from the AMC, whereas only 4 per cent of them depended on common public taps. Conversely, among households in the insecure tenure category, 19 per cent had individual water taps provided by the AMC, whereas 52 per cent depended on common public taps. In strong de facto tenure slums, all households had access to toilets, whereas in the insecure tenure category slums, 2 per cent, and in the weak de facto tenure category 5 per cent, did not have any toilet access and hence were defecating in the open. Among the households that had access to toilets, 94 per cent of them in the strong de facto tenure category and 69 per cent in the insecure tenure category had an individual household toilet. Thus, even in insecure tenure category households had managed to build individual toilets through the AMC scheme. In slums in the insecure tenure category, 18 per cent of households used community toilets, albeit constructed by the AMC.

The literacy rate among households with some $d e$ facto tenure is higher than the households without any tenure security. Male and female literacy rates among the households living in insecure settlements are 72 per cent and 55 per cent, respectively, while the rates for households living in settlements with strong de facto tenure security are 81 per cent and 58 per cent, respectively. We do not find any difference between households with strong and weak tenure security conditions as far as adult literacy is concerned. Surprisingly, there is a higher proportion of children going to school among households living in insecure tenure category than among households with strong tenure $d e$ facto tenure security. This outcome needs to be further investigated using variables of caste.

Male and female work participation rates do not show any relation to tenure category, but quality of employment does. There is a very high incidence of casual labour work, which in India is an unskilled, low wage activity, and hence an indicator of poverty (Dubey and Mahadevia 2001; Dubey and Gangopadhyay 1998). Among men, the incidence of casual employment increases with tenure insecurity: 82 per cent of employed men in settlements with insecure tenure worked as casual labour, whereas 51 per cent of men in settlement with strong de facto tenure security did so. In fact, the incidence of employment in private sector services where higher skill levels and regularity of work are required is high among settlements with strong de facto tenure security -34 per cent of men and 53 per cent of women were working in these jobs. In contrast, just 16 per cent of men and 48 per cent of women 


\begin{tabular}{|c|c|c|c|c|c|}
\hline S. No & Dependent variable & B & SE & $\mathbf{Z}$ & $\operatorname{Exp}(B)$ \\
\hline 1 & Pucca housing & $0.705^{*}$ & 0.258 & 2.737 & 2.024 \\
\hline 2 & More than two rooms & 0.288 & 0.262 & 1.097 & 1.333 \\
\hline 3 & Individual toilet connection & -0.046 & 0.307 & -0.150 & 0.955 \\
\hline 4 & Individual bath & 0.342 & 0.288 & 1.189 & 1.408 \\
\hline 5 & Connection to sewer line & -0.278 & 0.368 & -0.755 & 0.758 \\
\hline 6 & Literate & $0.448^{*}$ & 0.238 & 1.886 & 1.565 \\
\hline 7 & Education beyond class 5 & $0.573^{*}$ & 0.237 & 2.419 & 1.773 \\
\hline 8 & Income of more than Rs3,000 & $0.779^{*}$ & 0.252 & 3.092 & 2.180 \\
\hline 9 & Household having more than six assets & 0.063 & 0.247 & 0.253 & 1.065 \\
\hline 10 & Household saving & 0.211 & 0.293 & 0.720 & 1.235 \\
\hline 11 & Availability of BPL card & $-1.098^{* *}$ & 0.814 & -1.349 & 0.334 \\
\hline 12 & Availability of voter card & $-1.732^{*}$ & 0.798 & -2.169 & 0.177 \\
\hline 13 & Member of a community organisation & 0.697 & 0.895 & 0.779 & 2.007 \\
\hline 14 & Member of a NGO & -.028 & 0.285 & -0.097 & 0.973 \\
\hline
\end{tabular}

${ }^{*} p<0.10 ;{ }^{* *} p<0.20$

$\mathrm{SE}=$ standard error; S.No = Serial No; B = Logistic Regression Coefficient; Z = Wald; Exp (B) = Odds ratio.

in settlements with insecure tenure were working in private services.

There is a strong positive correlation between tenure security and income. The per capita income of households in slums with strong de facto tenure is Rs908, in households in slums with weak de facto tenure is Rs895 and for households in insecure tenure status is Rs744. With this higher income, resulting from better employment options and an NGO organising savings, the proportion of households saving is highest among the slums with strong de facto tenure (34 per cent), followed by households living in the insecure tenure category (23 per cent of households are saving). Instead of the tenure factor, this NGO intervention in savings has resulted in higher savings incidence in insecure tenured slums as compared with weak de facto tenure slums.

However, the amount saved depends upon per capita incomes: the higher the per capita income, the higher the monthly savings per household.

In our surveyed slums, about 18 per cent of households do not have a ration card and only 19 per cent have a BPL card. The incidence of ration cards is higher among the households with some de facto tenure status (85 per cent and
88 per cent of households in the strong and weak tenure categories, respectively had a ration card), whereas 27 per cent of households in the insecure tenure category do not have a ration card. Thus the mis-targeting of subsidised schemes and facilities can be seen in this survey. However, the availability of voter ID cards is only weakly related to tenure status, given that 92 per cent of eligible voters had a voter ID card.

The bivariate logit regressions show that of the different factors that constitute tenure security, duration of residence in a slum has a very significant role (Table 3).

The results presented in Table 3 are among those where we could observe a significant relationship between duration of stay of more than 20 years and social protection outcome variables. The duration of stay is not related to (or does not have any impact on) the availability of water from the urban local body, the AMC; the availability of a toilet at household level; the participation of the household in NGO activities; one person from the household being a member of a community organisation; the household's awareness about development programmes; the possibility of child or children going to school; the presence of a 
sewer line in the settlement or having more than two rooms in the house. This means that these outcomes are influenced by other factors involved in tenure security level. However, duration of stay of more than 20 years in the settlement significantly and positively impacts quality of housing, the probability of being literate, achieving education level beyond class 5 and monthly household income of more than Rs3,000. All these coefficients are significant at the 90 per cent level. If a household is living in a settlement for more than 20 years, then the likelihood of it having a pucca house increases by 202 per cent; the likelihood of being literate by 156 per cent; of individuals in the household going beyond class 5 in education increases by 177 per cent and the likelihood of household income being above Rs3,000 per month, by 218 per cent.

Years of stay has a negative and significant impact on the likelihood of holding a BPL card. This is self-explanatory, as income increases with duration of residence in a settlement. The probability of a household holding a BPL card decreases by 67 per cent if it has been in a settlement for more than 20 years. However, duration of stay has a negative relationship with availability of voter cards. Thus, duration of stay is an important component of tenure security, but explains only certain achievements with regard to social protection. This leaves room for community action (in the case of Ahmedabad through an NGO-led intervention) and for state policy.

\section{Conclusions}

This article presents preliminary findings from primary research in one ward of Ahmedabad City. This ward was located on the periphery of the former geographic boundary of the city, and thus had limited access to public facilities. The city's development in Ahmedabad, as in most cities in India, is occurring through accretion and not through planning and strong public policy intervention. In recent years, in response to economic reforms, public policy interventions in cities have led to displacements, creating vulnerabilities and pushing the poorest out of the city (Mahadevia 2008b).

This article shows that the lives of the urban poor improve incrementally, through their own efforts. Duration of stay plays an important role in improving quality of life and social protection. However, when these efforts are supported by a state policy of extending de facto tenure, improvement can be faster. Gujarat's policy has been 'poor left to their own devices till the trickle down benefits reach them', in that tenure, security is attained through non-intervention by the state. This works until the state becomes proactive in the promotion of economic growth, as has occurred in India since the early 1990s. The first phase of development since economic reforms has been a story of displacements and marginalisations in urban areas, and in the metropolitan cities in particular, mainly because there has been inaction on the part of the state in protecting the poor, and active support for the urban infrastructure development that has caused displacements.

In such a scenario of state non-action, given Ahmedabad's history of voluntary organisations, NGOs have intervened to facilitate improvement in quality of life and to enable people to obtain their entitlements. NGO intervention has also hastened incremental improvements in quality of life. Some proactive state intervention such as extension of basic services also has similar effects to NGO intervention. The combined effect of non-intervention (measured through duration of stay), NGO intervention and state policy is captured by the tenure status variable.

This paper argues that in the absence of either land policy or slum policy extending secure tenure to the slum dwellers, perceived security of tenure has mattered. This perceived security of tenure, or what we call de facto tenure, emerges from many factors rather than a single public action, and improvements in quality of life and achievements in social protection are outcomes of a combination of factors involved in tenure security.

Improvement in physical quality of life and hence, reduction in deprivations are strongly linked: the higher the degree of de facto tenure security of a slum settlement, the higher is the residents' physical quality of life. Incomes and savings are also related to tenure levels and so is quality of employment. However, the incidence of savings is related to other institutional interventions such as NGO programmes. The literacy rate and the incidence of children going to school is not related to tenure status (as defined by aggregating all the defining factors). It is possible that literacy and education status are influenced by some of the factors defining aggregate tenure, and therefore a disaggregated analysis would help to explore a possible relationship. 


\section{Notes}

* Acknowledgements are due to Ms Bijal Bhatt of MHT, Rajendra Joshi of Saath, Niraj Jani of Urban Resource Centre of Saath for assisting in data collection, Pooja Shah for data collection and Pavan Ankinpalli for statistical analysis.

1 Within the context of 'Eminent Domain' of the state.

2 This study is part of a larger study carried out in two locations in Ahmedabad City and one location in Surat city. The findings presented here are from one location in Ahmedabad City.

3 The city's polity has taken a communal turn from mid-1980s, bringing the first Hindu right-wing political party to power at the city level since the late 1980s and at the state level from mid-1990s. The period of mid-1980s to the beginning of this century saw spate of communal violence in the city resulting in segregation of the Hindu and Muslim population (Mahadevia 2007b). Very few wards in the city therefore have mixed communities. Vasna ward, selected for the survey reported in this article, is on the boundary of the Hindu ward and the adjoining ward is a Muslim population dominated ward. There is a road in between, which was called a 'border' during the 2002 communal violence engineered by the Hindu right-wing forces. These communal divisions and city-managed infrastructure often have implications for public policy implementation. For the purpose of this article and its hypothesis, we have not gone into any details of this dimension of public space in Ahmedabad City however.

4 For details of SNP, see Acharya and Parikh (2002); Joshi (2002); Dutta (2002).

5 The 1998 slum estimate is from the Swarna Jayanti Shehri Rojgar Yojana (SJSRY) survey;

\section{References}

Acharya, S.K. and Parikh, S. (2002) 'Slum Networking in Ahmedabad: An Alternate Approach', in A. Kundu and D. Mahadevia (eds), Poverty and Vulnerability in a Globalising Metropolis: Ahmedabad, Delhi: Manak Publishers: 349-72

ASAG (1992) 'Census of Poverty Pockets in Ahmedabad', unpublished study sponsored by the Ahmedabad Municipal Corporation, Ahmedabad: Ahmedabad Study Action Group

Dubey, A. and Gangopadhyay, S. (1998) 'Occupational Structure and Incidence of the 2001 estimate is from the Ahmedabad Municipal Corporation (AMC) as given in Ahmedabad's CDP (http://jnnurm.nic.in/ missioncities.htm).

6 The number of households in a slum was calculated through a survey conducted by SEWA and SAATH. The total slum population has been calculated considering a family size of five. As per census figures of 2001, a population of 439,843 reside in slums. This figure has not been considered as it includes only those slums which have clusters of more than 60 houses.

7 As per the presentation by the Ahmedabad Municipal Corporation at a National Workshop on Approaches to Lands for the Urban Poor in India, organised by the Ministry of Housing and Urban Poverty Alleviation, Government of India and CEPT University, Ahmedabad, 17 April 2009.

8 This component contains the following seven facilities: (1) water supply to individual households; (2) sewerage to individual households; (3) individual toilets; (4) roads and paving; (5) storm water drainage; (6) street lighting and (7) tree plantation.

9 This component consists of formation of neighbourhood groups, women's groups (Mahila Mandal) and youth groups (Yuvak Mandal), with the active involvement of $\mathrm{NGO}(\mathrm{s})$ involved.

10 Based on data obtained from MHT and Saath, both NGOs implementing the SNP in Ahmedabad.

11 Indicators spanning level of living, employment category and asset possession, are used to get a composite index of household level achievements. A cut-off is decided and households below this cut-off are defined as Below Poverty Line (BPL) households.

Poverty in Urban Sector by Size Class of Towns', in M. Agarwal, A. Barua, S.K. Das and M. Pant (eds), Indian Economy in Transition, New Delhi: Har-Anand Publications: 92-106

Dubey, A. and Mahadevia, D. (2001) 'Poverty and Inequality in Indian Metropolises', The Indian Journal of Labour Economics 44.2: 223-42

Durand-Lasserve, Alain and Royston, Lauren (2002) Holding Their Ground, London: EarthScan Publications

Dutta, S.S. (2002) 'Partnerships for Urban Poverty Reduction: A Review of Experience', in A. Kundu and D. Mahadevia (eds), Poverty 
and Vulnerability in a Globalising Metropolis: Ahmedabad, Delhi: Manak Publishers: 237-67

Edwards, M. (1983) 'Residential Mobility in a Changing Housing Market: The Case of Bucaramnaga, Colombia', Urban Studies 20.2: 131-45

Gilbert, Alan (2001) On The Mystery of Capital and The Myths Of Hernando De Soto: What Difference Does Legal Title Make?, www.n-aerus.net/web/ sat/workshops/2001/papers/gilbert.pdf (accessed 27 February 2010)

Hamer, A.M. (1985) Bogota's Unregulated Subdivisions: The Myths and Realities of Incremental Housing Construction, World Bank Staff Working Paper 734, Washington DC: The World Bank

Hansen, E. and Williams, J. (1987) 'Economic Issues and the Progressive Housing Development Model', in C.V. Patton (ed.), Spontaneous Shelter - International Perspectives and Prospects, Philadelphia: Temple University Press: 303-25

Hirway, I. and Mahadevia, D. (2005) The Gujarat Human Development Report, 2004, Ahmedabad: Mahatma Gandhi Labour Institute

Joshi, R. (2002) 'Integrated Slum Development: Case of Pravinnagar-Guptanagar', in A. Kundu and D. Mahadevia (eds) Poverty and Vulnerability in a Globalising Metropolis: Ahmedabad, Delhi: Manak Publishers: 268-308

Keare, D.H. and Parris, S. (1982) Evaluation of Shelter Programs for the Urban Poor, World Bank Staff Working Paper 547, Washington DC: The World Bank

Mahadevia, D. (2008a) 'Metropolitan Employment in India', in D. Mahadevia (ed.), Inside the Transforming Urban Asia: Policies, Processes and Public Actions, New Delhi: Concept: 56-93

Mahadevia, D. (2008b): 'Inside Urbanising Asia', in D. Mahadevia (ed.), Inside the Transforming Urban Asia: Policies, Processes and Public Actions, New Delhi: Concept: 1-55

Mahadevia, D. (2007a) 'House that for the Aam Aadmi?', The Indian Express, 11 September 2007, www.indianexpress.com/story/215596.html

Mahadevia, D. (2007b) 'A City with Many Borders - Beyond Ghettoisation in
Ahmedabad', in A. Shaw (ed.), Indian Cities in Transition, Hyderabad: Orient Longman: 315-40

Mahadevia, D. (2002) 'Changing Economic Scenario: Informalisation and Increased Vulnerability', in A. Kundu and D. Mahadevia (eds), Poverty and Vulnerability in a Globalising Metropolis: Ahmedabad, Delhi: Manak Publishers: 30-79

Mahadevia, D. and Brar, H.S. (2008) 'Changes and Continuities in Development Priorities', in D. Mahadevia (ed.), Inside the Transforming Urban Asia: Policies, Processes and Public Actions, New Delhi: Concept: 132-67

Oberlander, P. (1985) Land: The Central Human Settlement Issue, Vancouver: University of British Columbia Press

Office of the Registrar General and Census Commissioner, India (2005) Slum Population, Series 1, Census of India, 2001, New Delhi: Office of the Registrar General and Census Commissioner, India

Payne, G. (2000). 'Urban Land Tenure Policy Options: Titles or Rights?', paper presented at the World Bank Urban Forum, Westfields Marriott, Virginia, 3-5 April, www.worldbank.org/html/fpd/urban/ forum2000/papers/realestate.pdf (accessed 22 March 2009)

Payne, G. (1997) Urban Land Tenure and Property Rights In Developing Countries, Rugby: Intermediate Technology Publications

Turner, J.F.C. (1968) 'Housing Priorities, Settlement Patterns, and Urban Development in Modernizing Countries', Journal of American Institute of Planners, November: 354-63

Turner, J.F.C. (1967) 'Barriers and Channels for Housing Development in Modernizing Countries', Journal of American Institute of Planners, May: 167-81

UNFPA (2007) State of World Population, 2007 Unleashing the Potential of Urban Growth, United Nations Population Fund, www.unfpa.org/swp/2007 